\title{
Marketing of Library Products and Services: A Study of Dr. Zakir Husain Library of Jamia Millia Islamia, Delhi and Central Library, Central University of Haryana, India
}

\author{
Manish Kumar*1, Shyam Nath Yadav ${ }^{2}$ \\ ${ }^{1,2}$ Department of Library and Information Science, Universeity of Delhi, INDIA \\ *Correspondence: kkmaniii2014@gmail.com
}

\begin{abstract}
The research work overtly presents the Marketing plan, strategies being used by university libraries of Dr. Zakir Husain Library of Jamia Millia Islamia, Delhi and Central Library, Central University of Haryana. A well structured questionnaire was administered to the librarian of selected libraries and after regular persuasion the duly filled in questionnaire was received. The analysis shows that both libraries are providing a number of services free of cost. Out of 26 services asked by librarians, Dr. Zakir Husain Library, JMI provides 23 services while Central University of Haryana gives only 16 services. This shows that Dr. Zakir Husain Library, JMI is better in terms of providing library services than Central Library, Central University of Haryana. The paper analyses the opinion regarding marketing concepts and Staff Attitude towards Marketing and its use in library. The study found that there is Lack of understanding about marketing among top management, Reluctance of users to pay for services, Lack of availability of promotional material, Lack of professional manpower and Lack of ICT infrastructure are major barriers in marketing library products and services.
\end{abstract}

KEYWORDS: Marketing, LIS products and Services, Barriers in Marketing, Marketing tools and techniques, Library Marketing

\section{INTRODUCTION}

The library attached to a University functions as auxiliary unit to academic and administrative activities and with passage of time it's nature, role, functions, collection and services are rapidly changing to meet the onslaught information needs of Internet era user's. Nowadays libraries are facing stiff challenge and competition from varied search engines being used to quench the information quests and thus it is inevitable for knowledge hubs to market its resources and services to apprise its clientele and satisfy their information needs timely. Marketing in real sense is promotion and also involve selling but not applicable to all libraries thus the objective is to promote library resources and services and effectively satisfy the information needs of its user's, intimate about new array of products and services, convince them what more can be done as per the user's demands/ requirements and how libraries are still the authentic service provider abodes of knowledge in Internet era.

\subsection{Marketing concept}

"It is envisage that marketing is essential for survival in present competitive environment as it reflects the collective efforts of employees with organization resources to satisfy clientele needs. Marketing emphasizes on deep analysis of organization goals, process and steps taken for satisfying the customer's requirements and keep them happy so that they will approach again and again and also do advocacy to others which augments client membership." (Kotler 10)

\subsection{Definitions of Marketing}

Kotler and Armstrong (2012) "the process by which companies create value for customers and build strong customer relationships in order to capture value from customers in return." .Baro \& Ebhomeya (2013) "marketing within a university library implies a need to identify its objectives and users, and be able to develop products and services that can appropriately meet their needs." 


\section{REVIEW OF LITERATURE}

The study by Hazam "Marketing of Information products and services with special reference to Allama Iqbal Library of University of Kashmir discusses the need and importance of marketing of information products and services in libraries with challenges in the process of marketing." (107-114)

Miracle Eka in her work "Marketing in the 21st century using communication modes in accessing information needs of students in two study centre libraries of National Open University of Nigeria shows that faculty of social science has greater percentage of students than other faculties and higher undergraduates than post graduate students, explains awareness on student use of library resources before and after marketing as medium, application of social media and use of course materials and past question papers were discovered to have greater impact at student in accessing their information needs. Lack of internet connectivity was a major hindrance by students in accessing available electronic resources at both study center libraries." (1-15)

Ogoegbunam, Ekwueme and Promise Ifeoma "study covers challenges and enhancement strategies for the marketing of library services for improved accessibility to students of National Open University of Nigeria (NOUN). Population for the study consists of 15 librarians from the six study centers libraries in the six geopolitical zones in Nigeria and results showed that there is no significant difference in the mean responses of librarians on strategies and methods employed in the various study centre libraries of NOUN for improved accessibility of the library services to their students. The study also highlighted challenges in process of marketing of library services for improved access includes; inadequate funding, lack of marketing plan, unavailability of online public access catalogue and negative attitude of librarians and library staff towards marketing." (1-23)

Khalid paper on "marketing and promotion plays a very vital role in creating awareness for library and information products and services. The work emphasized on marketing and promotion in academic libraries with particular reference to Central Library, University of Malaya, Kuala Lumpur. The objectives of the study are to identify the available information resources and services in the Central Library and to unveil the strategies used by Central Library in marketing its resources and services with suggestions to librarians to promote their libraries through exhibitions and displays, publicity and public relations." (50-59)

Osinulu, et al... "investigated marketing strategies employed by librarians in a state university library in Nigeria. The study adopted survey research design of expost facto type. A validated questionnaire with Cronbach Alpha Reliability Coefficient of 0.69 was used to gather information from all the librarians. The results revealed that user survey studies, books, interlibrary loan services and improved burrowing privileges were prevalent marketing strategies used by librarians. Unstable Internet connectivity and inadequate funding were identified as major challenges to effective marketing of library products and services. The study recommended use of ICT and social media tools; teaching of innovative marketing concepts and principles in Nigerian Library schools and aggressiveness on the part of librarians." (18-32)

According to Siva and Gopalakrishnan "The whole process is to prepare a plan, analysis, understanding the clientele requirements and fulfilling them with effective services. It seems libraries are not using marketing tools and techniques in systematic way and the user's are either ignorant or unaware and thus it is essential to apply marketing strategies effectively." (177-188)

Olorunfemi and Adeola Ipadeola "have examined the need for marketing library and information services in university libraries in South West Nigeria; techniques being employed by university libraries in marketing of library and information services; competencies required of librarians in marketing of library and information services; challenges being faced by the librarians in marketing of library and information services and strategies for enhancing marketing of library and information services in South West Nigeria. The finding shows that provision of electronic access to information, staff friendliness to users, exhibitions and display of new arrivals, creating a library web page, organizing user education, and one on one discussion with users are techniques being employed in marketing library and information services. Good communication skills, information technology skills, ability to answer users' query, ability to sell idea/library services, are competencies required of librarians in marketing library and information services. Major challenges are; inadequate fund, management lack of marketing policy, lack of facilities to market library services, lack of media access to market academic library services, poor access to information technology, lack of training in marketing, and lack of effective communication between librarians and users." (1-15)

\section{NEED OF STUDY}

The change and challenges faced by present day libraries immediately require proactive approach by essentially marketing of library resources which is inevitable to promote library collection and resources, to study and analyse the user's information needs and to satisfy them, to make them aware of library strengths and to deliver the services through social media and Internet means. Marketing section is popular and widely accepted for all libraries due to the growing interest in library management and marketing issues. It is necessary to identify the market scope to formulate appropriate policies and principles of a library. University Library with a huge collection of books, journals, manuscripts 
and other collections rarely have planning and principles to establish of marketing its products. A fruitful marketing program enhances both image and betterment of its services. Some steps are taken occasionally and unconsciously but no specific measures are taken for betterment of the marketing library and information product in University Library.

There are number of studies have been conducted in order to study the application of marketing tools and techniques in universities library in India. Most of them has focused articles Marketing of Information Products and Services, Marketing Library and Information Services, Marketing of Library Resources and Marketing Strategies for Information Services. While analyzing the papers, it was found that there is no paper on marketing which has focused on studying the application of marketing in University Libraries in Delhi in recent times. Therefore, the need was felt that it is necessary to study and find out the whether the university libraries are marketing of their products and services or not and if they are than explore the process by undertaking a study. Thus, the statement of Problem defined as "Marketing of Library Products and Services by Dr. Zakir Husain Library of Jamia Millia Islamia, Delhi and Central Library, Central University of Haryana: A Study"

\section{OBJECTIVES OF THE STUDY}

i. To know about the application of marketing concept and strategies by these selected libraries.

ii. To check the marketing policies being used in the selected universities libraries.

iii. To find out varied Library products and Services being marketing by the libraries.

iv. To check the effectiveness of marketing tools used by the libraries.

v. To study the pricing policy of Library products and services.

vi. To give suggestions for effective marketing of library products and services.

\section{Scope of the Study}

The research tangibly reveals picture of LIS products and services provided by select University Libraries under study, users' information needs and existing scenario of marketing strategies, marketing environment, marketing tools and techniques employed and futuristic approach. The present study is confined to two Central University Libraries viz. Dr. Zakir Husain Library, Jamia Millia Islamia, Delhi and Central Library, Central University of Haryana. The study only provides the librarians opinion and observation of both libraries received through questionnaires. The study is trying to find out what marketing tools and techniques are employed to make aware the current users' and entice the corporate clients, and numerous related queries, issues, strategies and hunches associated with marketing of
LIS products and services has been quenched by the present study.

\section{DATA COLLECTION}

For research one well-structured questionnaire for the librarian was designed and sent through e-mail in the first week of May month and after regular persuasion, the duly filled questionnaires were received back from both librarians. The data collected through that has been analyzed, tabulated and presented in entitled Data Analysis and Interpretation.

\section{Data Analysis and Interpretation}

In this section the data is collected through questionnaire have been analyzed and presented in a comparative manner with a view to identify the Marketing of Library Products and Services by Dr. Zakir Husain Library, JMI and Central Library, Central University of Haryana, Haryana. Dr. Zakir Husain Library, JMI was established in the year 1920 while Central Library, Central University of Haryana, Haryana was established in 2009 and both are part of Central Universities.

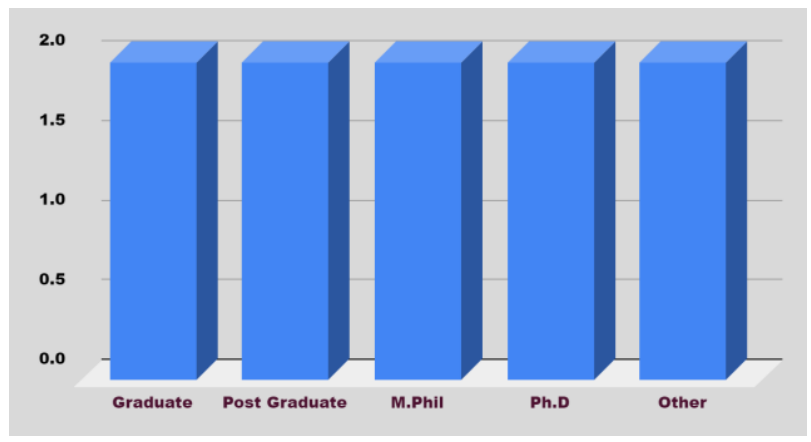

Figure 7.1: Library Membership

Figure 7.1 shows the library membership which is given to bonafide student's include Graduate, Post Graduate, M.Phil. and PhD including Teaching and Non-Teaching Staff.

Table 7.2: Sources of Finance

\begin{tabular}{|l|l|l|l|}
\hline S.N. & Sources of Finance & $\begin{array}{l}\text { Dr. Zakir } \\
\text { Husain } \\
\text { Library, JMI }\end{array}$ & $\begin{array}{l}\text { Central Library, } \\
\text { Central } \\
\text { University of } \\
\text { Haryana }\end{array}$ \\
\hline $\mathbf{1}$ & $\begin{array}{l}\text { Institutional } \\
\text { Grant }\end{array}$ & $\checkmark$ & - \\
\hline $\mathbf{2}$ & UGC Grant & $\checkmark$ & $\checkmark$ \\
\hline $\mathbf{3}$ & Special Grant & - & - \\
\hline $\mathbf{4}$ & Library Fee & - & - \\
\hline $\mathbf{5}$ & Library Fine & - & - \\
\hline $\mathbf{6}$ & $\begin{array}{l}\text { Marketing of } \\
\text { Library Products } \\
\text { \& Services }\end{array}$ & - & - \\
\hline
\end{tabular}

The data of 7.2 shows sources of finance for both the libraries. Central Library, Central University of Haryana receives only UGC Grant and Dr. Zakir Husain Library, JMI receives both Institutional Grant as well as UGC Grant. Both libraries does not have any other source of 
finance like Special Grant, Library Fee, Library Fine and Marketing of Library Products and Services.

Table 7.3: Opinion Regarding Marketing Concepts

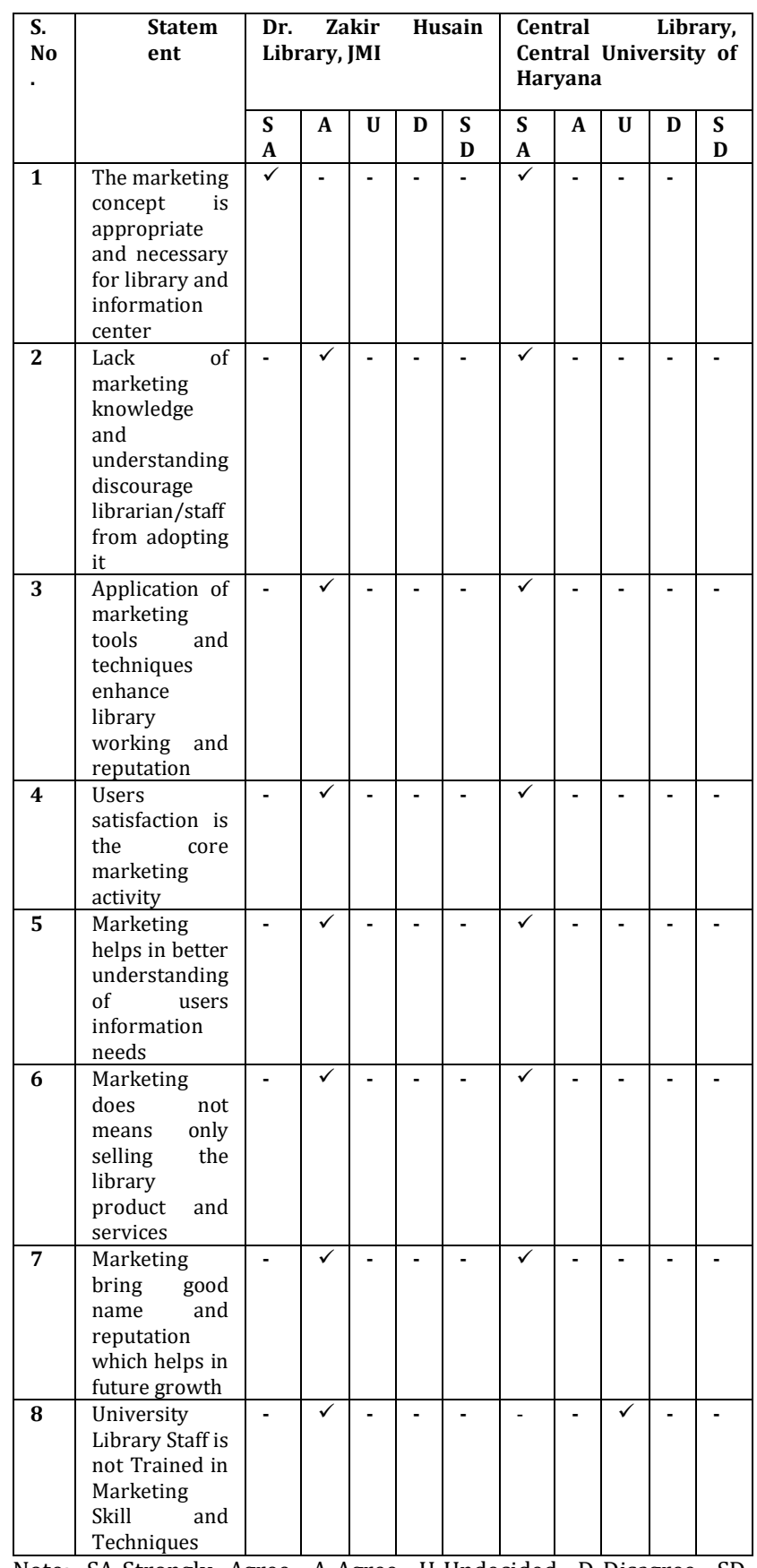

Note: SA-Strongly Agree, A-Agree, U-Undecided, D-Disagree, SDStrongly Disagree

It is found that librarian of Central University of Haryana (CUH) is completely and strongly agreed with all the statements from 1-7 while JMI librarian is strongly agreed with only statement 1 i.e. "The marketing concept is appropriate and necessary for library and information center'. Further, CUH librarian is strongly agreed with statement 2 i.e. 'Lack of marketing knowledge and understanding discourage librarian/staff from adopting it' while librarian of Dr. Zakir Husain, JMI is agreed only. In case of statement 3 i.e. 'Application of marketing tools and techniques enhance library working and reputation' CUH librarian is strongly agreed and Dr. Zakir Husain,JMI librarian is agreed only. CUH librarian strongly agreed with statement 4 i.e. 'Users satisfaction is the core marketing activity' while librarian of Dr. Zakir Husain, JMI is agreed only. In case of statement 5 i.e. 'Marketing helps in better understanding of users information needs' CUH librarian is strongly agreed and Dr. Zakir Husain librarian is agreed only. In case of statement 6 i.e. 'Marketing does not means only selling the library product and services' CUH librarian is strongly agreed and librarian of Dr. Zakir Husain library agreed only. Further, CUH librarian is strongly agreed with statement 7 i.e. 'Marketing bring good name and reputation which helps in future growth' while librarian of Dr. Zakir Husain library, JMI is agreed only. With statement 8 i.e. 'University Library Staff is not trained in Marketing Skill and Techniques' the librarian of Dr. Zakir Husain library, JMI is agreed but the librarian of Central Library, Central University of Haryana is undecided or having neutral opinion.

Table 7.4: Staff Attitude about Marketing

\begin{tabular}{|c|c|c|c|c|c|c|c|c|c|c|c|}
\hline \multirow[t]{2}{*}{$\begin{array}{l}\text { S. } \\
\text { No } \\
\text {. }\end{array}$} & \multirow[t]{2}{*}{$\begin{array}{l}\text { Stateme } \\
\text { nts }\end{array}$} & \multicolumn{5}{|c|}{$\begin{array}{l}\text { Dr. Zakir } \\
\text { Library JMI }\end{array}$} & \multicolumn{5}{|c|}{$\begin{array}{l}\text { Central Library, } \\
\text { Central University of } \\
\text { Haryana }\end{array}$} \\
\hline & & $\begin{array}{l}\text { S } \\
\text { A }\end{array}$ & A & $\mathbf{U}$ & D & $\begin{array}{l}\text { S } \\
\text { D }\end{array}$ & $\begin{array}{l}\text { S } \\
\text { A }\end{array}$ & $\mathbf{A}$ & $\mathbf{U}$ & D & $\begin{array}{l}\text { S } \\
\text { D }\end{array}$ \\
\hline 1 & $\begin{array}{l}\text { Lack of } \\
\text { marketing } \\
\text { knowledge and } \\
\text { understanding } \\
\text { is a deterrent } \\
\text { for staff in } \\
\text { accepting and } \\
\text { adopting it }\end{array}$ & $\checkmark$ & - & - & - & - & - & $\bar{v}$ & - & - & - \\
\hline 2 & $\begin{array}{l}\text { Communicatio } \\
n \text { skills of staff } \\
\text { is important } \\
\text { for assessing } \\
\text { the users } \\
\text { information } \\
\text { need }\end{array}$ & - & $\checkmark$ & - & - & - & $\checkmark$ & - & - & - & - \\
\hline 3 & $\begin{array}{lr}\text { Library } & \text { staff } \\
\text { should } & \text { be } \\
\text { trained } & \text { in } \\
\text { marketing } & \\
\text { practices } & \text { to } \\
\text { deal } & \text { with } \\
\text { challenges } & \end{array}$ & - & $\checkmark$ & - & - & - & $\checkmark$ & - & - & - & - \\
\hline 4 & $\begin{array}{l}\text { There should } \\
\text { be a separate } \\
\text { unit with } \\
\text { skilled } \\
\text { professionals } \\
\text { to handle } \\
\text { marketing } \\
\text { activities }\end{array}$ & - & $\bar{v}$ & - & - & - & $\checkmark$ & - & - & - & - \\
\hline
\end{tabular}

Note: SA-Strongly Agree, A-Agree, U-Undecided, D-Disagree, SDStrongly Disagree

Regarding the attitude of library staff towards the marketing, it is observed that statement 1 i.e. 'Lack of marketing knowledge and understanding is a deterrent for staff in accepting and adopting it' only librarian of Zakir Husain library, JMI is strongly agreed whereas the librarian of Central Library, Central University of Haryana agreed only. With regard to statements 2 to 4 i.e. 'Communication skills of staff is important for 
assessing the users information need', 'Library staff should be trained in marketing practices to deal with challenges' and 'There should be a separate unit with skilled professionals to handle marketing activities' the librarian of CUH library is strongly agreed but the librarian of Dr. Zakir Husain Library, JMI is agreed only.

Table 7.5: Library and Information Science Products and Services

\begin{tabular}{|c|c|c|c|c|c|c|c|c|c|}
\hline \multirow[t]{2}{*}{ S.N. } & \multirow[t]{2}{*}{ Services } & \multicolumn{4}{|c|}{$\begin{array}{l}\text { Dr. Zakir Husain } \\
\text { Library, JMI }\end{array}$} & \multicolumn{4}{|c|}{$\begin{array}{l}\text { Central Library, } \\
\text { Central University of } \\
\text { Haryana }\end{array}$} \\
\hline & & Yes & No & C & NC & Yes & No & C & NC \\
\hline 1 & Circulation & $\checkmark$ & - & - & $\checkmark$ & $\checkmark$ & - & - & $\checkmark$ \\
\hline 2 & References & $\checkmark$ & - & - & $\checkmark$ & $\checkmark$ & - & - & $\checkmark$ \\
\hline 3 & $\begin{array}{l}\text { Current } \\
\text { awareness } \\
\text { service (CAS) }\end{array}$ & $\checkmark$ & - & - & $\checkmark$ & $\checkmark$ & - & - & $\checkmark$ \\
\hline 4 & $\begin{array}{l}\text { Selective } \\
\text { dissemination } \\
\text { of information } \\
\text { (SDI) }\end{array}$ & $\checkmark$ & - & - & $\checkmark$ & - & $\checkmark$ & - & - \\
\hline 5 & Bibliographic & - & $\checkmark$ & - & - & - & $\checkmark$ & - & - \\
\hline 6 & Indexing & $\checkmark$ & - & - & $\checkmark$ & - & $\checkmark$ & - & - \\
\hline 7 & Abstracting & - & $\checkmark$ & - & - & - & $\checkmark$ & - & - \\
\hline 8 & $\begin{array}{l}\text { News paper } \\
\text { clipping }\end{array}$ & $\checkmark$ & - & - & $\checkmark$ & $\checkmark$ & - & - & $\checkmark$ \\
\hline 9 & Photocopy & $\checkmark$ & - & - & $\checkmark$ & $\checkmark$ & - & - & $\checkmark$ \\
\hline 10 & Translation & - & $\checkmark$ & - & - & - & $\checkmark$ & - & - \\
\hline 11 & E- Resources & $\checkmark$ & - & - & $\checkmark$ & $\checkmark$ & - & - & $\checkmark$ \\
\hline 12 & $\begin{array}{l}\text { Referral } \\
\text { services }\end{array}$ & $\checkmark$ & - & - & $\checkmark$ & $\checkmark$ & - & - & $\checkmark$ \\
\hline 13 & $\begin{array}{lr}\text { In- } & \text { house } \\
\text { database } & \text { and } \\
\text { products }\end{array}$ & $\checkmark$ & - & - & $\checkmark$ & - & $\checkmark$ & - & - \\
\hline 14 & $\begin{array}{l}\text { Audio - visual } \\
\text { service }\end{array}$ & $\checkmark$ & - & - & $\checkmark$ & $\checkmark$ & - & - & $\checkmark$ \\
\hline 15 & $\begin{array}{l}\text { Document } \\
\text { Delivery }\end{array}$ & $\checkmark$ & - & - & $\checkmark$ & - & $\checkmark$ & - & - \\
\hline 16 & $\begin{array}{l}\text { Inter library } \\
\text { loan }\end{array}$ & $\checkmark$ & - & - & $\checkmark$ & $\checkmark$ & - & $\checkmark$ & - \\
\hline 17 & $\begin{array}{l}\text { Notification of } \\
\text { New Research }\end{array}$ & $\checkmark$ & - & - & $\checkmark$ & $\checkmark$ & - & - & $\checkmark$ \\
\hline 18 & $\begin{array}{l}\text { Research } \\
\text { Report }\end{array}$ & $\checkmark$ & - & - & $\checkmark$ & $\checkmark$ & - & - & $\checkmark$ \\
\hline 19 & Patent Records & $\checkmark$ & - & - & $\checkmark$ & - & $\checkmark$ & - & - \\
\hline 20 & $\begin{array}{l}\text { New Product } \\
\text { Records }\end{array}$ & $\checkmark$ & - & - & $\checkmark$ & $\checkmark$ & - & - & $\checkmark$ \\
\hline 21 & $\begin{array}{l}\text { Marketing } \\
\text { Analysis } \\
\text { Projects }\end{array}$ & $\checkmark$ & - & - & $\checkmark$ & - & $\checkmark$ & - & - \\
\hline 22 & $\begin{array}{l}\text { Training to LIS } \\
\text { Professionals }\end{array}$ & $\checkmark$ & - & - & $\checkmark$ & $\checkmark$ & - & - & $\checkmark$ \\
\hline 23 & $\begin{array}{l}\text { Information } \\
\text { literacy } \\
\text { programmers }\end{array}$ & $\checkmark$ & - & - & $\checkmark$ & $\checkmark$ & - & - & $\checkmark$ \\
\hline 24 & $\begin{array}{l}\text { Notification of } \\
\text { Conferences, } \\
\text { Workshops etc. }\end{array}$ & $\checkmark$ & - & - & $\checkmark$ & $\checkmark$ & - & - & $\checkmark$ \\
\hline 25 & $\begin{array}{l}\text { Preparation of } \\
\text { projects }\end{array}$ & $\checkmark$ & - & - & $\checkmark$ & $\checkmark$ & - & - & $\checkmark$ \\
\hline 26 & $\begin{array}{l}\text { Consultancy } \\
\text { Service }\end{array}$ & $\checkmark$ & - & - & $\checkmark$ & - & $\checkmark$ & - & - \\
\hline
\end{tabular}

Note: C means Chargeable and NC Not Chargeable

Table 7.5 shows the various services provided by the respective libraries. Dr. Zakir Husain Library, JMI provides 23 services out of 26 whereas Central Library, Central University of Haryana provides 16 out of 26 services which reflects that Dr. Zakir Husain Library, JMI is better in terms of providing library services than Central Library, Central University of Haryana. Further, JMI library does not charge fees for any of its service but in Central Library, Central University of Haryana only
Inter library loan service is chargeable. The Translation, Bibliographic and Abstracting services are not provided by both libraries. Central Library, Central University of Haryana does not provide Marketing Analysis Projects, Consultancy Service, Document Delivery service, Inhouse database and products, Patent Records and Selective dissemination of information (SDI) services while Dr. Zakir Husain Library, JMI provides it.

Table 7.6: Marketing Tools and Techniques used for Promotion of LIS products and Services

\begin{tabular}{|c|c|c|c|c|c|}
\hline \multirow[t]{2}{*}{ S.N. } & \multirow[t]{2}{*}{ Statement } & \multicolumn{2}{|c|}{$\begin{array}{l}\text { Dr. Zakir } \\
\text { Husain } \\
\text { Library, JMI }\end{array}$} & \multicolumn{2}{|c|}{$\begin{array}{l}\text { Central } \\
\text { Library, } \\
\text { Central } \\
\text { University of } \\
\text { Haryana }\end{array}$} \\
\hline & & Yes & No & Yes & No \\
\hline 1 & Online Advertisement & - & $\checkmark$ & $\checkmark$ & - \\
\hline 2 & Library Website & $\checkmark$ & - & $\checkmark$ & - \\
\hline 3 & $\begin{array}{l}\text { User Orientation } \\
\text { Programme }\end{array}$ & $\checkmark$ & - & $\checkmark$ & - \\
\hline 4 & Personal Contact & $\checkmark$ & - & $\checkmark$ & - \\
\hline 5 & Leaflets & $\checkmark$ & - & $\checkmark$ & - \\
\hline 6 & Poster & $\checkmark$ & - & $\checkmark$ & - \\
\hline 7 & Pamphlets & - & $\checkmark$ & $\checkmark$ & - \\
\hline 8 & Broachers & $\checkmark$ & - & $\checkmark$ & - \\
\hline 9 & E-mails & $\checkmark$ & - & $\checkmark$ & - \\
\hline 10 & Bulletin boards & $\checkmark$ & - & - & $\checkmark$ \\
\hline 11 & Notice boards & $\checkmark$ & - & $\checkmark$ & - \\
\hline 12 & $\begin{array}{ll}\begin{array}{l}\text { Participation } \\
\text { exhibitions }\end{array} & \text { in } \\
\end{array}$ & $\checkmark$ & - & $\checkmark$ & - \\
\hline 13 & $\begin{array}{l}\text { Advertisement in } \\
\text { newspaper/journals }\end{array}$ & - & $\checkmark$ & $\checkmark$ & - \\
\hline 14 & $\begin{array}{lr}\text { Marketing } & \text { through } \\
\text { presentation } & \text { in } \\
\text { conference } & \text { /seminar } \\
\text { /workshops } & \\
\end{array}$ & $\checkmark$ & - & $\checkmark$ & - \\
\hline 15 & Discussion Groups & $\checkmark$ & - & $\checkmark$ & - \\
\hline 16 & Oral presentations & $\checkmark$ & - & $\checkmark$ & - \\
\hline 17 & Newsletters & - & $\checkmark$ & $\checkmark$ & - \\
\hline 18 & Articles & - & $\checkmark$ & $\checkmark$ & - \\
\hline 19 & $\begin{array}{l}\text { Social media like } \\
\text { YouTube }\end{array}$ & - & $\checkmark$ & $\checkmark$ & \\
\hline 20 & LinkedIn & - & $\checkmark$ & $\checkmark$ & - \\
\hline 21 & Twitter & - & $\checkmark$ & $\checkmark$ & - \\
\hline 22 & Facebook & $\checkmark$ & - & $\checkmark$ & - \\
\hline 23 & Wikis & - & $\checkmark$ & $\checkmark$ & - \\
\hline
\end{tabular}

From the above table 7.6 it is found that both libraries are promoting their products and services with help of different tools and techniques mentioned in the table. Both methods of promotion i.e. Traditional and Web based are being adopted by the libraries. Central Library, Central University of Haryana (CUH) is using 22 types of marketing tools out of 23 while Dr. Zakir Husain Library, JMI uses only 15 out of 23 marketing tools and techniques. This shows that CUH Library is better in terms of using marketing tools and techniques for promoting its products and services than Dr. Zakir Husain Library, JMI. Dr. Zakir Husain Library have not used the tools and Techniques for Promotion of LIS products and Services i.e. Newsletters, Articles, Social media like YouTube, Linkedin, Twitter, Wikis, Advertisement in newspaper/ journals, Online Advertisement and Pamphlets and the Central Library, 
Central University of Haryana have not used Bulletin boards for promotion of LIS products and services.

Table 7.7: Benefits of Marketing Tools and Techniques

\begin{tabular}{|c|c|c|c|c|c|}
\hline \multirow[t]{2}{*}{ S.N. } & \multirow[t]{2}{*}{ Statement } & \multicolumn{2}{|c|}{$\begin{array}{l}\text { Dr. Zakir } \\
\text { Husain } \\
\text { Library, } \\
\text { JMI }\end{array}$} & \multicolumn{2}{|c|}{$\begin{array}{l}\text { Central } \\
\text { Library, } \\
\text { Central } \\
\text { University } \\
\text { of Haryana }\end{array}$} \\
\hline & & Yes & No & Yes & No \\
\hline 1 & To increase membership & $\checkmark$ & - & $\checkmark$ & - \\
\hline 2 & $\begin{array}{l}\text { To bring awareness among } \\
\text { users about library products } \\
\text { and services }\end{array}$ & $\checkmark$ & - & $\checkmark$ & - \\
\hline 3 & $\begin{array}{l}\text { To understand the } \\
\text { information needs of users } \\
\text { effectively }\end{array}$ & $\checkmark$ & - & $\checkmark$ & - \\
\hline 4 & $\begin{array}{l}\text { To help in better utilization } \\
\text { of library resources }\end{array}$ & $\checkmark$ & - & $\checkmark$ & - \\
\hline 5 & $\begin{array}{l}\text { To improve the library } \\
\text { functioning and reputation }\end{array}$ & $\checkmark$ & - & $\checkmark$ & - \\
\hline 6 & To generate revenue & & $\checkmark$ & - & $\checkmark$ \\
\hline
\end{tabular}

Analysis of the above table 7.7 reveals that librarian's of both libraries Central Library, Central University of Haryana and Dr. Zakir Husain Library, JMI are agreed with all the statements from 1-5 and disagreed with the statement no 6 i.e. 'To generate revenue'. The analysis indicates that librarian's are using marketing to increase their membership, increase the awareness level among students as well as to improve the library functioning and reputation.

Table 7.8: Barriers in Marketing Library Products and Services

\begin{tabular}{|c|c|c|c|c|c|}
\hline \multirow[t]{2}{*}{ S.N. } & \multirow[t]{2}{*}{ Statement } & \multicolumn{2}{|c|}{$\begin{array}{l}\text { Dr. Zakir } \\
\text { Husain } \\
\text { Library, } \\
\text { JMI }\end{array}$} & \multicolumn{2}{|c|}{$\begin{array}{l}\text { Central } \\
\text { Library, } \\
\text { Central } \\
\text { University of } \\
\text { Haryana }\end{array}$} \\
\hline & & Yes & No & Yes & No \\
\hline 1 & $\begin{array}{l}\text { Lack of understanding about } \\
\text { marketing among top } \\
\text { management }\end{array}$ & $\checkmark$ & - & $\checkmark$ & - \\
\hline 2 & $\begin{array}{lcc}\begin{array}{l}\text { Idea of } \\
\text { welcomed } \\
\text { professionals }\end{array} & \text { by } & \text { LIS } \\
& & \\
\end{array}$ & $\checkmark$ & - & - & $\checkmark$ \\
\hline 3 & $\begin{array}{l}\text { Lack of recognition of concept } \\
\text { by users }\end{array}$ & - & $\checkmark$ & $\checkmark$ & - \\
\hline 4 & $\begin{array}{l}\text { Reluctance of users to pay for } \\
\text { services }\end{array}$ & $\checkmark$ & - & $\checkmark$ & - \\
\hline 5 & $\begin{array}{l}\text { Lack of availability of } \\
\text { promotional material }\end{array}$ & $\checkmark$ & - & $\checkmark$ & - \\
\hline 6 & $\begin{array}{l}\text { Lack of professional } \\
\text { manpower }\end{array}$ & $\checkmark$ & - & $\checkmark$ & - \\
\hline 7 & $\begin{array}{l}\text { Lack of adequate funds for } \\
\text { marketing activities }\end{array}$ & - & $\checkmark$ & $\checkmark$ & - \\
\hline 8 & $\begin{array}{l}\text { Lack of ICT infrastructure to } \\
\text { handle marketing activities }\end{array}$ & $\checkmark$ & - & $\checkmark$ & - \\
\hline
\end{tabular}

Analysis of the above table 7.8 reveals that librarian of both libraries Central Library, Central University of Haryana and Dr. Zakir Husain Library, JMI are agreed with the statements 1,4,5,6 and 8. Central Library, Central University of Haryana is disagreed with the statement no 2 i.e. 'Idea of marketing not welcomed by LIS professionals' while Dr. Zakir Husain Library JMI library is disagreed with statement 3 and 7 . The analysis indicates that both the libraries are facing 'Lack of understanding about marketing among top management', 'Reluctance of users to pay for services', 'Lack of availability of promotional material', 'Lack of professional manpower and Lack of ICT infrastructure' as major barriers in marketing library products and services.

\section{Major Findings}

1. It is found that JMI Library has a budget of Rs 1.6 crores out of which 1.20 crores for purchase of Print and Electronic Resources and Rs 40 lakhs for Books. Central Library of CHU has a total budget of Rs 6.88 crores out of which Rs. 1.0 crore for purchase of print and electronic resources, Rs. 35 lakhs for books, Rs 1.0 lakh for marketing purposes and Rs10, 000 for miscellaneous expenses.

2. Both libraries provide membership to Graduate, Post Graduate, M.Phil and Ph.D including Teaching and Non-Teaching Staff. Membership is given to the users on prior permission from the library by showing letter from their concerned supervisor.

3. Central Library, Central University of Haryana receives only UGC Grant and Dr. Zakir Husain Library receives both Institutional Grant as well as UGC Grant.

4. With regard to table no. 5.3 i.e. Opinion Regarding Marketing Concepts, various questions were asked to the librarian and in relation to statement 1 i.e. 'The marketing concept is appropriate and necessary for library and information center' the Librarian of CUH library strongly agreed and JMI librarian only agreed. With regard to statement no.2 'Lack of marketing knowledge and understanding discourage librarian/staff from adopting it' the CUH librarian strongly agreed and JMI librarian only agreed. In relation to statement no. 3 i.e. 'Application of marketing tools and techniques enhance library working and reputation' the CUH librarian strongly agreed while JMI librarian only agreed. With regard to statement no. 4 'Users satisfaction and the core marketing activity' the CHU librarian strongly agreed and JMI librarian agreed only.

5. With regard to table no. 7.4 i.e. Staff Attitude about marketing, various questions were asked to the librarian and in relation to statement 1 i.e. 'Lack of marketing knowledge and understanding is a deterrent for staff in accepting and adopting it' the librarian of Dr. Zakir Husain library, JMI strongly agreed while CUH librarian agreed only. With regard to statement no.2 'Communication skill of staff is important for assessing the user's information need' the librarian of CUH library strongly agreed while Dr. Zakir Husain library, JMI librarian agreed only. In relation to statement no. 3 i.e. 'Library staff should be trained in marketing practices to deal with challenges' the librarian of 
CUH strongly agreed and Dr. Zakir Husain library, JMI librarian agreed only. With regard to statement no. 4 'There should be a separate unit with skilled professionals to handle marketing activities' the librarian of CUH strongly agreed while Dr. Zakir Husain library, JMI librarian agreed only.

6. Both the libraries are providing a number of services free of cost. Central Library, Central University of Haryana has chargeable Inter library loan service. Translation, Bibliographic and Abstracting services (in house) are not provided by both libraries. Central Library, Central University of Haryana does not provide Marketing Analysis Projects, Consultancy Service, Document Delivery services, In- house database and products, Patent Records and Selective dissemination of information (SDI) services while Dr. Zakir Husain Library JMI provides it.

7. Dr. Zakir Husain Library, JMI provides 23 services out of 26 while Central Library, Central University of Haryana gives only 16 out of 26 services. This shows that Dr. Zakir Husain Library, JMI is better in terms of providing library services than Central Library, Central University of Haryana.

8. It is found that both the libraries are promoting their products and services with help of different marketing tools and techniques. Both methods of promotion i.e. Traditional and Web based are being adopted by the libraries. Newsletters, Articles, Social media like YouTube, LinkedIn, Twitter, Wikis, and Advertisement in newspaper/ journals, Online Advertisement and Pamphlets are not used by Dr. Zakir Husain Library for promotion.

9. Central Library, Central University of Haryana (CUH) is using 22 types of marketing tools out of 23 while Dr. Zakir Husain Library, JMI uses only 15 out of 23 marketing tools and techniques. This shows that CUH Library is better in terms of using marketing tools and techniques for promoting its products and services than Dr. Zakir Husain Library.

10.The analysis indicates that both the librarian's are facing Lack of understanding about marketing among top management, Reluctance of users to pay for services, Lack of availability of promotional material, Lack of professional manpower and Lack of ICT infrastructure as major barriers in marketing of library products and services.

\section{CONCLUSION}

From the findings of the study it can be concluded that Central Library, CUH is using marketing tools and techniques for promoting its LIS products and services in much better way as compare to Dr. Zakir Husain library, JMI. CUH library is having a specific budget for the marketing and promotion activities but Dr. Zakir Husain library, JMI lacks in it. It is revealed that Dr. Zakir Husain library, JMI is providing better and more services than CUH library as the reason is JMI library is well established (100 year old) while CUH library is just 11 year old only. Library authority of both libraries must understand and implement marketing strategies essential for effective services and user's satisfaction. It is imperative to take regular feedbacks to bring changes and improvement inevitable for effective services. Marketing focuses on promotional activities to better understand the information needs of clientele to take appropriate and effective steps taken for enhancement of membership and clientele satisfaction.

\section{REFERENCES}

Anil Kumar. "Marketing of Information Products \& Services in Kurukshetra University Library in the Disciplines of Social Science: A study.” IOSR Journal Of Humanities And Social Science (IOSR-JHSS) Vol.19, no 2, 2014, pp. 72-85.

Bhatt, R.K., Amit Kumar and Md. Yusuf. "Marketing of LIS Products and Services in Select Economics Libraries in Delhi." DESIDOC Journal of Library \& Information Technology, Vol. 36, No. 3, 2016, pp. 131-142, publications.drdo.gov.in/ojs/ index .php/djlit/ article/view /9794/55 98. Accessed on 25 March 2020.

Billah, Bilkis. Marketing Library and Information Products of Dhaka University Library. University Of Dhaka. MA dissertation, 2014, repository. library. du.ac.bd/ bitstre am/handle/12 3456789/830/Bilkis\%20Billah.pdf?sequence $=1 \quad$ \&is Allowed=y. Accessed on 25 March 2020.

Eka, Njeze Miracle. "21st Century Marketing Using Communication Modes by Students in Accessing Their Information Needs at Two Selected Study Center Libraries in Southwest of National Open University of Nigeria." Library Philosophy and Practice, 2018, pp. 1-15, digitalcommons.unl.edu/libphilprac/2062/?Utmsourc edigitalcommons.unl.edu\%2Flibphilprac\%2F2062\&u tmmediumPDF\&utmcampaignPDFCoverPages.Acce ssed on7 Apr. 2020.

Hazam, Manzoor Ahmed. "Marketing of information products and services: A case study of Allama Iqbal Library, University of Kashmir, Srinagar." IP Indian Journal of Library Science and Information Technology.vol. 2, no. 2, 2017, pp. 107-114, www.researchgate.net/publication/318107898. Accessed on 7Apr. 2020.

Juryiah, Siti. and Mohd, Khalid. "Marketing of Library and Information Services in Üniversity Libraries: A Case Study of Üniversity of Malaya Central Library, Kuala Lumpur, Malaysia." The Eurasia Proceedings of Educational \& Social Sciences (EPESS), vol. 13, 2019, pp. 50-59, www.isres.org. Accessed on 7Apr. 2020. 
Khan, Milan and Kamal, Mostafa. "Marketing of Library and Information Services in University Libraries: A Practical Experience." Asian Journal of Multidisciplinary Studies, Vol.4, no.1, 2016, pp. 2026.www.ajms.co.in/sites/ajms2015/index.php/ ajms/article/view/1473. Accessed on 25 March 2020.

Kotler, Philip, and Armstrong, Gary. Principle of Marketing. 12th ed., Pearson Education International, $2008 . \quad$ Epdf.pub/principles-of-marketing-12thedition94464c501bab $\quad 5659 \mathrm{~d} \quad 6248$ c6d54ff642d36733.html. Accessed on 25 March 2020.

Lovacate, Atuhaire. A marketing plan for improving information services at kibubura girls' secondary school library. Makerere University, Undergraduate dissertation. 2019, dissertations .mak. ac.ug/handle /20 $.500 .12281 / 6505$. Accessed on 25 March 2020.

Mittal, P., \& Raghuvaran, S. (2021). Entrepreneurship education and employability skills: the mediating role of e-learning courses. Entrepreneurship Education, 4(2), 153-167. https://doi.org/10.1007/s41959-02100048-6

Olorunfemi, Micheal and Ipadeola, Deborah Adeola, "Marketing Library and Information Services in Selected University Libraries In South West Nigeria." Library Philosophy and Practice (e-journal).1975, 2018,pp. 1-15.

Osinulu, Lolade F., et al. "Marketing Strategies used by Librarians in A State University Libraries." University of Dar es Salaam Library Journal. vol 13, no 2, 2018, pp-18-32,

www.ajol.info/index.php/udslj/article/download/1845 9 6/173 953. Accessed on 7Apr. 2020

Rita, Eda and Sandra Ejiro, Ukubeyinje. "Strategies for Marketing Library Services and Information products in College of Education." International Journal of Research and Innovation in Social Science (IJRISS).vol. 3, no. 9, 2019, pp 29-33, www.rsisin ternational.org/journals/ijriss/Digital-Library/volume3-issue-9/29-33.pdf. Accessed on 7Apr. 2020.

Siva, B and Gopalakrishnan, S. "Attitude on Marketing among Selected Central University Library and Information Science Professionals: A Study." International Journal of Human Resource Management and Research. vol. 8, no. 6, 2018, pp.177-188. 